CHAVES, AP; BEZERRA NETO, F; LIMA, JSS; SILVA, JN; NUNES, RLC; BARROS JÚNIOR, AP; LIMA, GKL; SANTOS, EC. 2020. Cowpea and beet intercropping agro-economic dynamics under spatial arrangement and cowpea population density. Horticultura Brasileira 38: 192-203. DOI - http://doi. org/10.1590/S0102-053620200212

\title{
Cowpea and beet intercropping agro-economic dynamics under spatial arrangement and cowpea population density
}

\author{
Aridênia P Chaves ${ }^{1 \mathbb{D}}$; Francisco Bezerra Neto ${ }^{1 \mathbb{D}}$; Jailma SS Lima ${ }^{1 \mathbb{D}}$; Josimar N Silva ${ }^{1 \mathbb{D}}$; Renato LC \\ Nunes ${ }^{2 *} \mathbb{D}$; Aurélio P Barros Júnior ${ }^{1 \mathbb{D}}$; Grace KL Lima ${ }^{1 \mathbb{D}}$; Elizangela C Santos ${ }^{1 \mathbb{D}}$
}

${ }^{1}$ Universidade Federal Rural do Semi-Árido (UFERSA), Mossoró-RN, Brasil; aridenia.peixoto@hotmail.com; bezerra@ufersa.edu.br; jailma@ufersa.edu.br; josimar2160@hotmail.com; aurelio.barros@ufersa.edu.br; gracekllagro@gmail.com; ${ }^{2}$ Instituto Federal do Ceará (IFCE), Limoeiro do Norte-CE, Brasil; renatoleandro.ce@hotmail.com (*corresponding author)

\begin{abstract}
The objective of this work was to evaluate the effect of planting spatial arrangements between the cowpea and beet crops in intercropping and of cowpea population densities on the crop's productivity and in the agro-economic efficiency of the association at two growing seasons. The experimental design was of randomised blocks with the treatments arranged in a $4 \times 3$ factorial scheme, in four replications. The first factor was constituted by three spatial arrangements between the component cultures (2:2, 3:3 and 4:4), formed by beet rows alternated with cowpea rows, while the second factor was constituted by the population densities of cowpea: 40, 60,80 and $100 \%$ of the recommended population in single crop (RDSC). The production and its components were evaluated in the beet and cowpea. Apart from these characteristics, the following agroeconomic indicators were also determined for each treatment: system productivity index (SPI), the land equivalent coefficient (LEC), and the monetary equivalent ratio (MER). The maximum production of commercial beet roots was obtained with $15.60 \mathrm{t} \mathrm{ha}^{-1}$ productivity at density of $61.82 \%$ of RDSC within the $4: 4$ arrangement, while the maximum yield of cowpea green grains of $2.23 \mathrm{t} \mathrm{ha}^{-1}$ was reached at density of $79.57 \%$ of RDSC within $2: 2$ spatial arrangement. The productivities of beet roots of extra A, extra AA and great types decreased with increasing cowpea population density, without any influence of the tested spatial arrangements. The maximum mean productivity of cowpea green pods of $1.74 \mathrm{t} \mathrm{ha}^{-1}$ was obtained at density of $87.47 \%$ of RDSC, reached within 2:2 spatial arrangement. The maximum economic efficiency of the cowpea-beet intercropping was obtained with MER of 1.11 at cowpea density of $100 \%$ of RDSC, irrespective of the spatial arrangement and growing season.
\end{abstract}

Keywords: Vigna unguiculata, Beta vulgaris, complementarity, mixed-cropping revenues.

\section{RESUMO}

Dinâmica agroeconômica do consórcio de caupi e beterraba sob arranjo espacial e densidade populacional de caupi

O objetivo deste trabalho foi avaliar o efeito de arranjos espaciais de plantio entre as culturas do caupi e beterraba em consórcio e de densidades populacionais de caupi na produtividade das culturas e na eficiência econômica do sistema em duas estações de cultivo. $\mathrm{O}$ delineamento experimental usado foi em blocos casualizados, com os tratamentos arranjados em esquema fatorial $4 \times 3$, em quatro repetições. O primeiro fator foi constituído por três arranjos espaciais entre as culturas componentes (2:2, 3:3 e 4:4), formados pelas linhas de caupi alternadas com as linhas de beterraba e o segundo fator pelas densidades populacionais do caupi: $40,60,80$ e $100 \%$ da densidade recomendada em cultura solteira (DRCS). As produções e seus componentes foram avaliados na beterraba e no feijão caupi. Além dessas características, também foram determinados os seguintes indicadores agroeconômicos para cada tratamento: índice de produtividade do sistema (IPS), coeficiente equivalente de terra (CET) e índice de equivalência monetária (IEM). A produção máxima de raízes comerciais de beterraba foi obtida com a produtividade de 15,60 t ha $^{-1}$ na densidade de caupi de $61,82 \%$ da DRCS no arranjo 4:4, enquanto o rendimento máximo de grãos verdes de caupi de 2,23 tha $^{-1}$ foi alcançado na densidade de 79,57\% da DRCS no arranjo espacial de plantio 2:2. As produtividades de raízes de beterraba dos tipos extra A, extra AA e grande diminuíram com o aumento da densidade populacional do caupi, sem qualquer influência dos arranjos espaciais testados. A produtividade média máxima de vagens de caupi verde de $1,74 \mathrm{t} \mathrm{ha}^{-1}$ foi obtida na densidade de $87,47 \%$ do DRCS, alcançada dentro do arranjo espacial 2:2. A eficiência econômica máxima do consórcio de caupi-beterraba foi alcançada com um IEM de 1,11 na densidade de caupi de $100 \%$ do DRCS, independentemente do arranjo espacial e da estação de cultivo.

Palavras-chave: Vigna unguiculata, Beta vulgaris, complementaridade, receitas em cultivo consorciado.

Received on January 22, 2020; accepted on May 8, 2020

$\mathrm{I}^{\mathrm{n}}$ ntercropping systems of vegetablecowpea and vegetables are beginning to be implemented in the Brazilian semi-arid region. These vegetables are of great food, agronomic, social and economic importance in family farming production systems. Cowpea (Vigna unguiculata) is one of the main legumes grown in the northeastern semi-arid region, standing out as one of the richest proteins and carbohydrates sources, essential elements for human nutrition 
(Ehlers, 1997; Andrade Júnior, 2007). Beet (Beta vulgaris) is a vegetable of high nutritional value, rich in sodium, iron and vitamin A. In addition, it has medicinal properties with laxative and acid-neutralizing action, and is very useful in the formation of red blood cells (Souza et al., 2003).

One of the major challenges for obtaining viable production systems with food crops and vegetables in crop association is the correct choice of production factors for obtaining high productivity and economic efficiency of the system. However, these production factors need to be properly managed to improve the use of the environmental resources and to increase productivity and product quality, as well as the agronomic-biological efficiency of the intercropped systems compared to monoculture systems. Among these factors is the planting spatial arrangement between component crops, population density of the crops, growing season, among others (Oliveira et al., 2015; Batista et al., 2016; Silva et al., 2018).

The planting spatial arrangement of the crops is an important productionfactor in the competition between crops, consequently, in the agronomicbiological efficiency of intercropping systems. Intra- and interspecific competition is established by the arrangement of the plants, by the spacings between and within planting rows and by the time at which competition begins, thus defining the distribution pattern of the plants in relation to the soil and determining the available area for each individual plant in the use of the environmental resources.

Therefore, to maximize crop productivity, competition between and/ or within the intercropping species should be reduced by arranging them in such a way that they can better use ambient resources, thereby enhancing the production and the quality of the products (Schons et al., 2009). Favacho et al. (2017), studying the influence of spatial arrangements in intercropping systems of vegetable cowpea and carrot in northeastern Brazil, observed that the $2: 2$ spatial arrangement provided the highest productive and economic efficiency of the intercropped systems. Silva et al. (2018), researching the effect of spatial arrangements $(2: 2,3: 3$ and $4: 4)$ in intercropped systems of beet with two successive lettuce crops in a semi-arid environment, did not observe influence of these spatial arrangements on the productive and economic efficiency of the intercropped systems.

On the other hand, studies on planting densities in intercropping systems are designed in part to enhance the productivity of the system and provide a rationalization of the necessary cultural treatments. Nevertheless, cultivated species increase its productivity up to a certain density, at if the threshold is reached, thus competition for area and nutrients plays an increased role, resulting in reduced photosynthesis rates and nutrient concentrations, with potential negative consequences for plant growth and crop productivity/ quality (Strassburger et al., 2010; Ribeiro et al., 2017;).

The influence of planting density on the yield of food crops and vegetables has been shown in studies carried out in the semi-arid northeast of Brazil by Ribeiro et al. (2018). These authors, studying the intercropping of cowpea and carrot crops at different population densities, observed greater agro-economic efficiency at $100 \%$ population density of the population recommended in single crop (RDSC) of cowpea, indicating a better use of environmental resources in the largest populations tested. On the other hand, Andrade Filho (2012), researching the effect of population densities of coriander and arugula crops in two successive crops, intercropped with beet in a semiarid environment, observed higher productivity of polyculture in the population densities of 40,40 and $50 \%$ of the recommended densities for single crops (RDSC) of coriander, arugula and beet and higher profitability at densities of 20,20 and $50 \%$ of the RDSC.

The growing season is another major factor for crops success in the intercropping systems, as it results in changes in water relations, as well as in temperature, photoperiod and solar radiation available to plants (Araújo et al., 2006; Nunes et al.,
2018). This last author, studying the agro-economic responsiveness of radish associations with cowpea in function of different amounts of $C$. procera, spatial arrangements and cropping seasons, observed difference in the performance of radish and cowpea in relation to cropping seasons, where the total and commercial radish roots productivities were higher in the second cropping season, while the productivity of green pods and yield of green grains of cowpea were superior in the first cultivation season.

In this context, the objective of this work was to evaluate the effect of planting spatial arrangements between the cowpea and beet crops in intercropping system as well as cowpea population densities on the crops productivity and the agro-economic efficiency of the association at two growing seasons.

\section{MATERIAL AND METHODS}

The study was carried out in the experimental area of the Rafael Fernandes Farm of the Universidade Federal Rural do Semi-Árido, Mossoró$\mathrm{RN}$, Brazil $\left(5^{\circ} 11^{\prime} \mathrm{S}, 37^{\circ} 20^{\prime} \mathrm{W}, 18 \mathrm{~m}\right.$ altitude) in the growing seasons 2016 and 2017. The climate of the region is semi-arid and, according to Köppen's climatic classification scheme, 'BShw' type, dry and very hot, with two distinct seasons: a dry season from June to January and a rainy season from February to May (Alvares et al., 2014). Maximum average temperature ranges between 32.1 and $34.5^{\circ} \mathrm{C}$, and minimum average temperature between 21.3 and $23.7^{\circ} \mathrm{C}$, with June and July being the coldest months; $1920 \mathrm{~kJ} \mathrm{~m}^{-2}$ average solar radiation and $685.3 \mathrm{~mm}$ average annual precipitation.

The soil of the experimental area has been classified according to the criteria established in the Brazilian Soil Classification System as typical Dystrophic Red Argisol (Rêgo et al., 2016), with the following properties: First growing season, $\mathrm{pH}=7.46, \mathrm{~N}=$ $0.51 \mathrm{~g} \mathrm{~kg}^{-1}$, Organic Matter $(\mathrm{OM})=$ $3.64 \mathrm{~g} \mathrm{~kg}^{-1}, \mathrm{P}=63.3 \mathrm{mg} \mathrm{dm}^{-3}, \mathrm{~K}^{+}=60.0$ $\mathrm{mg} \mathrm{dm}{ }^{-3}, \mathrm{Ca}^{+2}=2.09 \mathrm{cmol}_{\mathrm{c}} \mathrm{dm}^{-3}, \mathrm{Mg}^{+2}=$ 
$0.58 \mathrm{cmol}_{\mathrm{c}} \mathrm{dm}^{-3}, \mathrm{Na}^{+}=17.0 \mathrm{mg} \mathrm{dm}^{-3}$, $\mathrm{EC}=1.77 \mathrm{ds} \mathrm{m}^{-1}, \mathrm{Cu}=0.19 \mathrm{mg} \mathrm{dm}^{-3}$, $\mathrm{Fe}=2.03 \mathrm{mg} \mathrm{dm}^{-3}, \mathrm{Mn}=10.43 \mathrm{mg} \mathrm{dm}^{-3}$, and $\mathrm{Zn}=6.21 \mathrm{mg} \mathrm{dm}^{-3}$. In the second growing season, the following results were obtained, $\mathrm{pH}=6.60, \mathrm{~N}=0.42 \mathrm{~g} \mathrm{~kg}^{-1}$, $\mathrm{OM}=3.65 \mathrm{~g} \mathrm{~kg}^{-1}, \mathrm{P}=34.2 \mathrm{mg} \mathrm{dm}^{-3}, \mathrm{~K}^{+}=$ $69.2 \mathrm{mg} \mathrm{dm}^{-3}, \mathrm{Ca}^{+2}=3.10 \mathrm{cmol}_{\mathrm{c}} \mathrm{dm}^{-3}$, $\mathrm{Mg}^{+2}=0.80 \mathrm{cmol}_{\mathrm{c}} \mathrm{dm}^{-3}, \mathrm{Na}^{+}=19.0 \mathrm{mg}$ $\mathrm{dm}^{-3}, \mathrm{EC}=0.10 \mathrm{ds} \mathrm{m}^{-1}, \mathrm{Cu}=0.29 \mathrm{mg}$ $\mathrm{dm}^{-3}, \mathrm{Fe}=2.86 \mathrm{mg} \mathrm{dm}^{-3}, \mathrm{Mn}=11.40 \mathrm{mg}$ $\mathrm{dm}^{-3}$, and $\mathrm{Zn}=7.35 \mathrm{mg} \mathrm{dm}^{-3}$.

The experimental design used was of randomised complete blocks with the treatments arranged in a $4 \times 3$ factorial scheme, with four replications, tested in the growing seasons 2016 and 2017. The first factor was constituted by different population densities of cowpea: 40, 60,80 and $100 \%$ of the recommended population in single crop (RDSC), while the second factor was constituted by three spatial arrangements between the component cultures $(2: 2,3: 3$ and $4: 4)$, formed by strips of beet alternated with strips of cowpea, consisting of two strips of two rows, in the 2:2 arrangement, two strips of three rows in the $3: 3$ arrangement, and two strips of four rows in the $4: 4$ arrangement, flanked by two beet border rows on one side and two border rows of cowpea on the other side, thereby constituting the side borders.

The recommended planting density in the northeastern region of Brazil for beet in single crop is 500,000 plants per hectare (Silva et al., 2010, 2011), while for cowpea, it is 200,000 plants per hectare (Pereira et al., 2016; Moraes et al., 2018). The planted cultivars of beet and cowpea were 'Early Wonder' and 'BRS Itaim', respectively, adapted to cultivation in this region.

The intercropping systems were established in alternating strips, using $50 \%$ of the area with beet and the other $50 \%$ of the area with cowpea, flanked by two border rows of each crop on each side. The total area of the plots in the spatial arrangements $2: 2,3: 3$, and $4: 4$ was $2.40,3.00$, and $3.60 \mathrm{~m}^{2}$, respectively, with harvest areas of $1.00,1.50$, and $2.00 \mathrm{~m}^{2}$. The spacing in the intercropping system was 0.25 $\mathrm{m}$ between rows, and within rows of cowpea, the spacing varied according to the population densities studied, which were $0.10,0.12,0.17$, and 0.25 $\mathrm{m}$, respectively. The spacing between beet plants was $0.04 \mathrm{~m}$.

In each block, plots of single crops of beet and cowpea were planted to obtain the agro-economic efficiency indices of the intercropping systems. For beet, the total plot area was $1.44 \mathrm{~m}^{2}$, with a harvest area of $0.80 \mathrm{~m}^{2}$, at $0.20 \times 0.10$ $\mathrm{m}$ spacing. For cowpea, the total area was $3.60 \mathrm{~m}^{2}$, with a harvest area of 2.00 $\mathrm{m}^{2}$, at $0.50 \times 0.10 \mathrm{~m}$ spacing.

The experiments were fertilized with green manure biomass of Calotropis procera, collected near the city of Mossoró-RN. Samples of this material were sent to the Laboratory of Soil Fertility and Plant Nutrition of UFERSA for chemical analysis, with the following results: $\mathrm{N}=18.40 \mathrm{~g} \mathrm{~kg}^{-1}, \mathrm{P}=3.10 \mathrm{~g} \mathrm{~kg}^{-1}$, $\mathrm{K}^{+}=4.50 \mathrm{~g} \mathrm{~kg}^{-1}, \mathrm{Ca}^{+2}=16.30 \mathrm{~g} \mathrm{~kg}^{-1}$ and $\mathrm{Mg}^{+2}=13.50 \mathrm{~g} \mathrm{~kg}^{-1}$ in the first growing season and $\mathrm{N}=15.30 \mathrm{~g} \mathrm{~kg}^{-1}, \mathrm{P}=0.66 \mathrm{~g}$ $\mathrm{kg}^{-1}, \mathrm{~K}^{+}=25.60 \mathrm{~g} \mathrm{~kg}^{-1}, \mathrm{Ca}^{+2}=8.60 \mathrm{~g} \mathrm{~kg}^{-1}$ and $\mathrm{Mg}^{+2}=4.32 \mathrm{~g} \mathrm{~kg}^{-1}$ in the second growing season.

Two incorporations of the green manure biomass in the intercropped systems and in the beet and cowpea plots in monoculture were carried out, with $20 \%$ of the biomass amount of $C$. procera being incorporated 20 days before planting (Moraes et al., 2018) and the remaining $80 \%$ at 20 days after planting (Silva et al., 2011), using the amounts recommended by previous studies in this region (Bezerra Neto et $a l ., 2013)$ for the respective cropping systems.

Planting of the component crops was carried out on September 14, 2016 and October 4, 2017, with direct sowing at $2 \mathrm{~cm}$ depth. After plant emergence, thinning was performed at 10 and 15 days for beet and cowpea, respectively, leaving one plant per hole. During the experiment, the crops were irrigated in two shifts (morning and afternoon), and weeding was performed manually as required.

Beets were harvested 70 days after sowing (DAS) in both seasons, while cowpea was harvested in four harvests at 55 to 65 days after planting in the respective growing seasons. After harvesting, the data were sent to the laboratory for evaluation.
The characteristics evaluated in the beet crop were plant height, shoots and roots dry mass, total and commercial productivity of roots, being the production classified as extra, extra A, extra AA, great, and scrap roots.

Length of green pods, number of green pods per square meter, productivity and dry mass of green pods, number of green grains per pod, weight of 100 green grains, yield, and dry mass of green grains were determined for the cowpea.

The agro-economic efficiency indices used in the evaluation of the intercropped systems were the system productivity index (SPI), the land equivalent coefficient (LEC), and the monetary equivalent ratio (MER).

The system productivity index was expressed by the formula (Pinto et al., 2011): $\mathrm{SPI}=\left[\left(\mathrm{Y}_{\mathrm{b}} / \mathrm{Y}_{\mathrm{c}}\right) \times \mathrm{Y}_{\mathrm{cb}}\right]+$ $Y_{b c}$, where $Y_{b}$ and $Y_{c}$ represent the productivity of commercially viable beet roots and the yield of green grains of cowpea in single crops, and $Y_{c b}$ is the yield of green grains of cowpea in intercropping with beet. Here, $\mathrm{Y}_{\mathrm{bc}}$ is the production of commercially viable roots in intercropping with cowpea. The main advantage of the SPI, expressed in $\mathrm{tha}^{-1}$, is that it standardizes the productivity of the secondary crop (cowpea) in terms of the main crop (beet).

The land equivalent coefficient (LEC) was calculated according to the methodology proposed by Adetiloye et al. (1983): $\mathrm{LEC}=\mathrm{LER}_{\mathrm{b}} \times \mathrm{LER}_{\mathrm{c}}$, where $\mathrm{LER}_{b}$ and $\mathrm{LER}_{\mathrm{c}}$ represent the partial land equivalent ratios of the beet and cowpea, respectively.

For intercropping between two cultures, the expected minimum coefficient of productivity is $25 \%$, i.e., the yield advantage becomes feasible if the value of the LEC exceeds 0.25 .

The monetary equivalent ratio was determined according to the methodology proposed by Adetiloye \& Adekunle (1989): $\mathrm{MER}=\left(\mathrm{GI}_{\mathrm{bc}}+\mathrm{GI}_{\mathrm{cb}}\right) /$ $\mathrm{GI}_{\mathrm{b}}$, where $\mathrm{GI}_{\mathrm{bc}}$ is the gross income of beet in intercropping with cowpea, $\mathrm{GI}_{\mathrm{cb}}$ is the gross income of cowpea in intercropping with beet, $\mathrm{GI}_{\mathrm{b}}$ is the highest gross income in single-crop $b$ culture when compared with that of the $c$ culture. This index measures the 
economic superiority, or otherwise, of the intercrop over the most economic sole crop.

Univariate analysis of variance for the randomized block design in a factorial scheme was used to evaluate the variables collected. A joint analysis for the two growing seasons was carried out, and Tukey's test was used to compare the means between the spatial arrangements and growing seasons, using the SISVAR software (Ferreira, 2011). An adjusting procedure of regression curves, using the Table Curve software, was used to estimate the behaviour of each variable as a function of the cowpea population densities studied (Jandel Scientific, 1991).

\section{RESULTS AND DISCUSSION}

The results of the analyses of the characteristics evaluated in the beet are presented in Table 1. Based on them, we observed that there was a significant interaction effect between growing seasons and spatial arrangements on beet plant height, with the mean heights of the 3:3 and 4:4 arrangements exceeding the mean heights of the plants in the 2:2 arrangement in the second growing season. No significant difference was observed between the mean plant heights as for the spatial arrangements within the first growing season.

On the other hand, studying the growing seasons within each arrangement, higher plant mean heights were recorded in the second season for the $4: 4$ arrangement. In the $2: 2$ and $3: 3$ arrangements, no significant differences were observed between the mean heights of plants, irrespective of the growing season. The behavior of this variable may be associated to a low synthesis of hormones present in the seed. In this way, there is an excessive growth of the stem, also called continuous plant etiolation, where the main consequence would be that the plants reach favorable heights to obtain light. According to Nunes et al. (2018), this performance can also be attributed to the influence of increased intraspecific competition for soil environmental resources.

Significant differences were recorded between cropping seasons for most of the beet variables, with higher values for the second season. In terms of the production of scrap roots, the opposite pattern was observed. This result may be related to the morphological growth behavior of vegetable cowpea, possibly causing less shading on the beet plants, resulting in a positive behavior in the yield of the beet roots. For dry mass of roots, no significant difference was recorded between cropping seasons.

This difference may also be related to the competitive and productive behaviour of cowpea between the growing seasons, since its performance was superior in the second season, positively favoring the beet performance in this same cropping. One environmental factor that may be related to performance is solar radiation. According to Midmore (1993), light sharing between species with contrasting adaptation to irradiance levels can go hand in hand with the competition for mineral nutrients in soil and water, influencing crop performance.

We found no significant differences among the spatial arrangements of the component cultures in the variables shoot dry mass, production of extra $A$, extra AA, great and scrap roots as well as for dry mass of roots. This behavior shows that the intraspecific

Table 1. Mean values for plant height (PH), dry mass of shoots (DMS), production of roots extra (PE), extra A (PEA), extra AA (PEAA), and great (PG), production of total (PT) and commercially viable roots (PC), production of scrap roots (PS) and dry mass of roots (DMR) of beet intercropped with cowpea at two growing seasons at different cowpea population densities and spatial arrangements. Mossoró, UFERSA, 2016-2017.

\begin{tabular}{|c|c|c|c|c|c|c|c|c|c|c|c|c|}
\hline \multirow{2}{*}{ Growing season } & \multirow{2}{*}{\multicolumn{3}{|c|}{ PH (cm) }} & DMS & $\mathbf{P E}$ & PEA & PEAA & PG & PT & PC & PS & DMR \\
\hline & & & & \multicolumn{9}{|c|}{$\left(\mathrm{t} \mathrm{ha}^{-1}\right)$} \\
\hline \multicolumn{4}{|l|}{1} & $1.84 \mathrm{~b}$ & $3.65 b$ & $2.86 \mathrm{~b}$ & $2.74 b$ & $1.99 \mathrm{~b}$ & $13.13 b$ & $11.24 b$ & $1.89 \mathrm{a}$ & $1.74 \mathrm{a}$ \\
\hline \multicolumn{4}{|l|}{2} & $2.25 \mathrm{a}$ & $4.70 \mathrm{a}$ & $4.38 \mathrm{a}$ & $5.04 \mathrm{a}$ & $3.97 \mathrm{a}$ & $19.73 \mathrm{a}$ & $18.06 \mathrm{a}$ & $1.67 \mathrm{~b}$ & $1.87 \mathrm{a}$ \\
\hline \multirow{2}{*}{$\begin{array}{l}\text { Spatial } \\
\text { arrangements }\end{array}$} & \multicolumn{3}{|c|}{ Seasons } & & & & & & & & & \\
\hline & & 1 & 2 & & & & & & & & & \\
\hline $2: 2$ & 43. & $7 \mathrm{aA}$ & $42.93 \mathrm{bA}$ & $2.09 a$ & & $3.57 \mathrm{a}$ & $4.21 \mathrm{a}$ & $2.86 \mathrm{a}$ & & & $1.73 \mathrm{a}$ & $1.69 \mathrm{a}$ \\
\hline $3: 3$ & 44. & $9 \mathrm{aA}$ & $44.88 \mathrm{aA}$ & $2.06 \mathrm{a}$ & & $3.59 \mathrm{a}$ & $3.78 \mathrm{a}$ & $3.35 \mathrm{a}$ & & & $1.80 \mathrm{a}$ & $1.93 \mathrm{a}$ \\
\hline $4: 4$ & 43. & $5 \mathrm{aB}$ & $46.41 \mathrm{aA}$ & $1.99 \mathrm{a}$ & & $3.71 \mathrm{a}$ & $3.67 \mathrm{a}$ & $2.73 \mathrm{a}$ & & & $1.80 \mathrm{a}$ & $1.79 \mathrm{a}$ \\
\hline \multirow{3}{*}{\multicolumn{2}{|c|}{$\begin{array}{l}\text { Cowpea population } \\
\text { densities (\% RDSC) }\end{array}$}} & \multicolumn{11}{|c|}{ Partitioning of the spatial arrangements within each population density for PE, PT and PC } \\
\hline & & \multicolumn{3}{|c|}{ PE $\left(\right.$ t ha $\left.^{-1}\right)$} & & \multicolumn{3}{|c|}{ PT $\left(\right.$ t ha $\left.^{-1}\right)$} & \multicolumn{4}{|c|}{ PC (t ha $\left.\mathbf{~ h}^{-1}\right)$} \\
\hline & & $2: 2$ & $3: 3$ & $4: 4$ & & $2: 2$ & $3: 3$ & 4.4 & & 2 & $3: 3$ & $4: 4$ \\
\hline 40 & & $5.61 \mathrm{H}$ & 4.47 & 4.05 & & $18.63 \mathrm{~A}$ & $19.67 \mathrm{~A}$ & 14.75B & & $.16 \mathrm{~A} \quad 1$ & $17.83 \mathrm{~A}$ & 13.03B \\
\hline 60 & & 4.05 & 4.45 & 4.23 & & $17.27 \mathrm{~A}$ & $16.30 \mathrm{~A}$ & $17.50 \mathrm{~A}$ & & $61 \mathrm{~A} \quad 1$ & $14.38 \mathrm{~A}$ & $15.68 \mathrm{~A}$ \\
\hline 80 & & $3.77 \mathrm{f}$ & 4.43 & 4.12 & & $16.33 \mathrm{~A}$ & $15.78 \mathrm{~A}$ & $16.93 \mathrm{~A}$ & & $\begin{array}{ll}.54 \mathrm{~A} & 1\end{array}$ & $13.85 \mathrm{~A}$ & $14.99 \mathrm{~A}$ \\
\hline 100 & & $3.23 \mathrm{H}$ & 4.21 & 3.99 & & $13.94 \mathrm{~A}$ & $15.75 \mathrm{~A}$ & $15.09 \mathrm{~A}$ & & $.90 \mathrm{~A} \quad 1$ & $14.23 \mathrm{~A}$ & $14.43 \mathrm{~A}$ \\
\hline
\end{tabular}

*Means followed by different lowercase letters within the same column or uppercase letters within the same row differ statistically, Tukey's test at the $5 \%$ probability level. 
competition within the beet culture was not influential for these growth and production variables.

Partitioning the interaction of the spatial arrangements within each cowpea population density in the production of extra, total, and commercially viable roots, we observed that only the $2: 2$ and 3:3 arrangements stood out from the $4: 4$ arrangement, in the population density $40 \%$ of RDSC (Table 1 ). In this case, intraspecific competition may have influenced the 4:4 arrangement, causing a reduction in production variables. This is due to a greater number of beet plants in simultaneous competition over natural resources. No significant differences between the spatial arrangements of the component crops in these variables within the other levels of cowpea population densities was observed.

Plant height and dry mass of shoots increased with increasing cowpea densities, reaching maximum values of $44.99 \mathrm{~cm}$ and $2.23 \mathrm{t} \mathrm{ha}^{-1}$ at densities of 43.93 and 44.27 of RDSC, respectively, with a subsequent decrease (Figures $1 \mathrm{~A}$ and $1 \mathrm{~B})$. The production of extra $\mathrm{A}$, extra AA and great roots decreased non-linearly with increasing cowpea densities (Figure 1D). Partitioning the interaction of population densities within each spatial arrangement, the production of extra roots decreased with increasing densities in the 2:2 and 3:3 arrangements (Figure 1C). These decreases in beet yields can be explained by interspecific competition, where the increase in the number of vegetable cowpea plants may have increased competition for soil nutrients, decreasing the effectiveness of beet plants with available nutrients. Pereira et al. (2016), studying the association of radish and vegetable cowpea in the same region of this research, also observed a decrease in the total and commercial productivity of the radish. Almeida et al. (2015) also obtained the same decreasing behavior of lettuce productivity and of yield of fresh arugula mass in intercropped cultivation.

On the other hand, in the $4: 4$ arrangement, extra productivity increased with increasing cowpea density, reaching a maximum value

Table 2. Mean values for length of green pods (LGP), number of green pods per $\mathrm{m}^{2}$ (NGP), productivity of green pods (PGP), dry mass of green pods (DMGP), number of green grains per pod (NGGP), weight of 100 green grains (W100GG), yield of green grains (YGG) and dry mass of green grains (DMGG) of cowpea intercropped with beet in two growing seasons, different cowpea population densities and spatial arrangements. Mossoró, UFERSA, 2016-2017.

\begin{tabular}{|c|c|c|c|c|c|c|c|c|c|c|}
\hline Growing seasons & LGP (cm) & $\operatorname{NGP}\left(\mathbf{m}^{2}\right)$ & \multicolumn{2}{|c|}{ PGP $\left(\mathrm{t} \mathrm{ha}^{-1}\right)$} & NGGP & W100GG (g) & \multicolumn{2}{|c|}{ YGG (t ha-1) } & \multicolumn{2}{|c|}{ DMGG $\left(\mathrm{t} \mathrm{ha}^{-1}\right)$} \\
\hline 1 & $15.76 \mathrm{a}$ & $99.21 \mathrm{a}$ & & & $6.97 \mathrm{~b}$ & $26.07 \mathrm{~b}$ & & & & \\
\hline 2 & $15.67 \mathrm{a}$ & $98.05 \mathrm{a}$ & & & $7.75 \mathrm{a}$ & $38.22 \mathrm{a}$ & & & & \\
\hline \multicolumn{11}{|l|}{ Spatial arrangements } \\
\hline $2: 2$ & $15.60 \mathrm{a}$ & $103.21 \mathrm{a}$ & \multicolumn{2}{|c|}{$1.68 \mathrm{a}$} & $7.40 \mathrm{a}$ & $34.43 a$ & \multicolumn{2}{|c|}{$1.84 \mathrm{a}$} & & \\
\hline $3: 3$ & $15.59 \mathrm{a}$ & $97.15 \mathrm{a}$ & \multicolumn{2}{|c|}{$1.46 \mathrm{~b}$} & $7.28 \mathrm{a}$ & $31.06 \mathrm{a}$ & \multicolumn{2}{|c|}{$1.55 \mathrm{~b}$} & & \\
\hline $4: 4$ & $15.96 \mathrm{a}$ & $95.54 \mathrm{a}$ & \multicolumn{2}{|c|}{$1.48 \mathrm{~b}$} & $7.41 \mathrm{a}$ & $30.95 \mathrm{a}$ & \multicolumn{2}{|c|}{$1.68 \mathrm{~b}$} & & \\
\hline \multirow{2}{*}{\multicolumn{3}{|c|}{$\begin{array}{l}\text { Cowpea population } \\
\text { densities (\%RDSC) }\end{array}$}} & \multicolumn{2}{|c|}{ Seasons } & & & \multicolumn{2}{|c|}{ Seasons } & \multicolumn{2}{|c|}{ Seasons } \\
\hline & & & 1 & 2 & & & 1 & 2 & 1 & 2 \\
\hline 40 & & & $1.14 \mathrm{~B}$ & $1.34 \mathrm{~A}$ & & & $0.87 \mathrm{~B}$ & $2.16 \mathrm{~A}$ & $0.54 \mathrm{~B}$ & $0.98 \mathrm{~A}$ \\
\hline 60 & & & $1.26 \mathrm{~B}$ & $1.79 \mathrm{~A}$ & & & $1.16 \mathrm{~B}$ & $2.17 \mathrm{~A}$ & $0.51 \mathrm{~B}$ & $0.69 \mathrm{~A}$ \\
\hline 80 & & & $1.32 \mathrm{~B}$ & $2.13 \mathrm{~A}$ & & & $1.41 \mathrm{~B}$ & $2.23 \mathrm{~A}$ & $0.55 \mathrm{~A}$ & $0.53 \mathrm{~A}$ \\
\hline 100 & & & $1.26 \mathrm{~B}$ & $2.12 \mathrm{~A}$ & & & $1.48 \mathrm{~B}$ & $2.01 \mathrm{~A}$ & $0.44 \mathrm{~A}$ & $0.49 \mathrm{~A}$ \\
\hline
\end{tabular}

Partitioning of the spatial arrangements within each cropping season for DMGP and DMGG, of cropping seasons within population densities for PGP and spatial arrangements within population densities for DMGG

\begin{tabular}{|c|c|c|c|c|c|c|}
\hline \multirow{2}{*}{ Growing seasons } & \multicolumn{3}{|c|}{ DMGP (t ha $\left.\mathbf{a}^{-1}\right)$} & \multicolumn{3}{|c|}{ DMGG $\left(\mathrm{t} \mathrm{ha}^{-1}\right)$} \\
\hline & $2: 2$ & $3: 3$ & $4: 4$ & $2: 2$ & $3: 3$ & $4: 4$ \\
\hline 1 & $0.36 \mathrm{aA} *$ & $0.30 \mathrm{aB}$ & $0.26 \mathrm{aC}$ & $0.59 \mathrm{aA}$ & $0.51 \mathrm{aB}$ & $0.43 \mathrm{bB}$ \\
\hline 2 & $0.23 \mathrm{bB}$ & $0.22 \mathrm{bB}$ & $0.27 \mathrm{aA}$ & $0.57 \mathrm{abB}$ & $0.67 \mathrm{aAB}$ & $0.78 \mathrm{aA}$ \\
\hline \multicolumn{7}{|c|}{$\begin{array}{l}\text { Cowpea population } \\
\text { densities (\% RDSC) }\end{array}$} \\
\hline 40 & $0.29 \mathrm{~B}$ & $0.32 \mathrm{~A}$ & $0.31 \mathrm{~A}$ & & & \\
\hline 60 & $0.33 \mathrm{~A}$ & $0.27 \mathrm{~B}$ & $0.25 \mathrm{~B}$ & & & \\
\hline 80 & $0.29 \mathrm{~A}$ & $0.25 \mathrm{~B}$ & $0.24 \mathrm{~B}$ & & & \\
\hline 100 & $0.24 \mathrm{~A}$ & $0.21 \mathrm{~A}$ & $0.25 \mathrm{~A}$ & & & \\
\hline
\end{tabular}

*Means followed by different lowercase letters in the column or uppercase in the line differ statistically from each other by the Tukey test at the $5 \%$ probability level. 
of $4.22 \mathrm{t} \mathrm{ha}^{-1}$ at density of $58.88 \%$ of RDSC, with a subsequent decrease (Figure 1C). This increase shows that the 4:4 arrangement of the beet provided greater intraspecific and even interspecific competition over the available natural resources, even with the increase in the density of vegetable cowpea.

These results disagree with those obtained by Ribeiro et al. (2018), studying the effects of cowpea population densities and spatial arrangements in carrot and cowpea intercropping; the authors obtained no interaction between these two production factors in terms of the production of total and commercially available roots. In turn, the authors stated that it was not possible to adjust response equations for such production as a function of cowpea population density. In terms of planting geometry, the total and commercially viable production of carrot roots in the 2:2 spatial arrangement was higher than in the other arrangements. In this study, however, the highest beet production values were obtained in the $2: 2$ and $3: 3$ arrangements, at a cowpea density of $40 \%$ of RDSC. These differences in results are due to the different tuberous cultures used in the intercropping with cowpea, thus behaving differently in competition in the planting arrangements and in the densities of cowpeas used.

Differently of the production behavior of extra A, extra AA and great roots, a reverse behaviour was observed for the production of scrap roots (Figure $2 \mathrm{~A}$ ), with a value of $2.05 \mathrm{tha}^{-1}$ obtained at a density of $100 \%$ of RDSC. This result shows, in part, the ability of interspecific competition to influence the amount of

Table 3. Mean values for system productivity index (SPI), land equivalent coefficient (LEC) and monetary equivalent ratio (MER) of cowpea intercropped with beet at two growing seasons and different spatial arrangements. Mossoró, UFERSA, 2016-2017.

\begin{tabular}{lcll}
\hline Growing seasons & SPI & LEC & MER \\
\hline 1 & $24.29 \mathrm{~b}^{*}$ & $0.52 \mathrm{a}$ & $1.02 \mathrm{~b}$ \\
2 & $30.96 \mathrm{a}$ & $0.57 \mathrm{a}$ & $1.14 \mathrm{a}$ \\
\hline Spatial arrangements & & & \\
\hline $2: 2$ & $28.99 \mathrm{a}$ & $0.59 \mathrm{a}$ & $1.11 \mathrm{a}$ \\
$3: 3$ & $26.98 \mathrm{~b}$ & $0.51 \mathrm{a}$ & $1.07 \mathrm{a}$ \\
$4: 4$ & $26.90 \mathrm{~b}$ & $0.53 \mathrm{a}$ & $1.05 \mathrm{a}$ \\
\hline
\end{tabular}

Beet in single crop 18.41

*Means followed by different lowercase letters within one column differ statistically by Tukey's test at the $5 \%$ probability level.

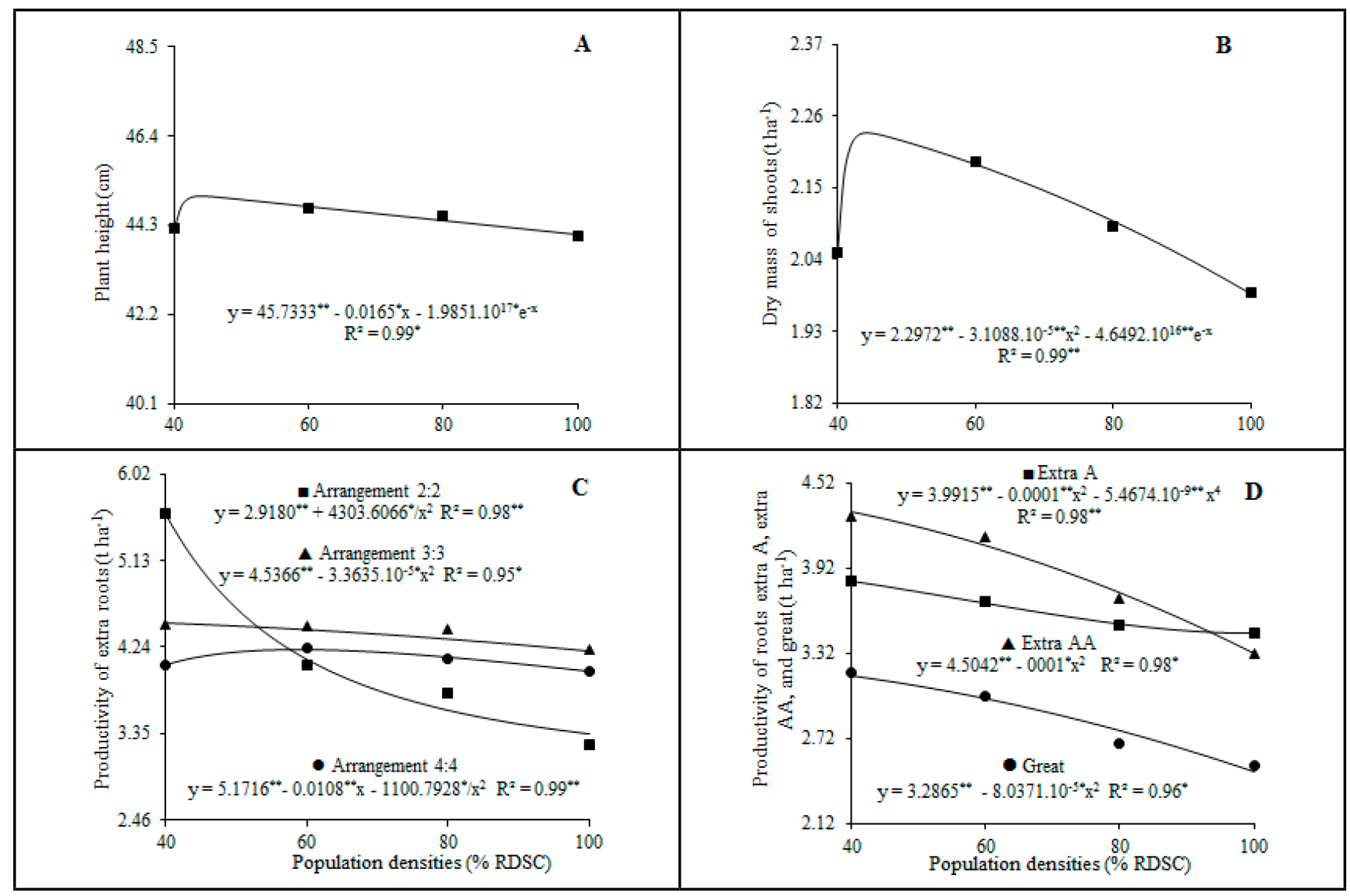

Figure 1. Plant height (A) and dry mass of beet shoots (B) intercropped with cowpea at different densities and production of roots extra (C), extra A, extra AA and great (D) of beet intercropped with cowpea at different spatial arrangements. Mossoró, UFERSA, $2016-2017$. 


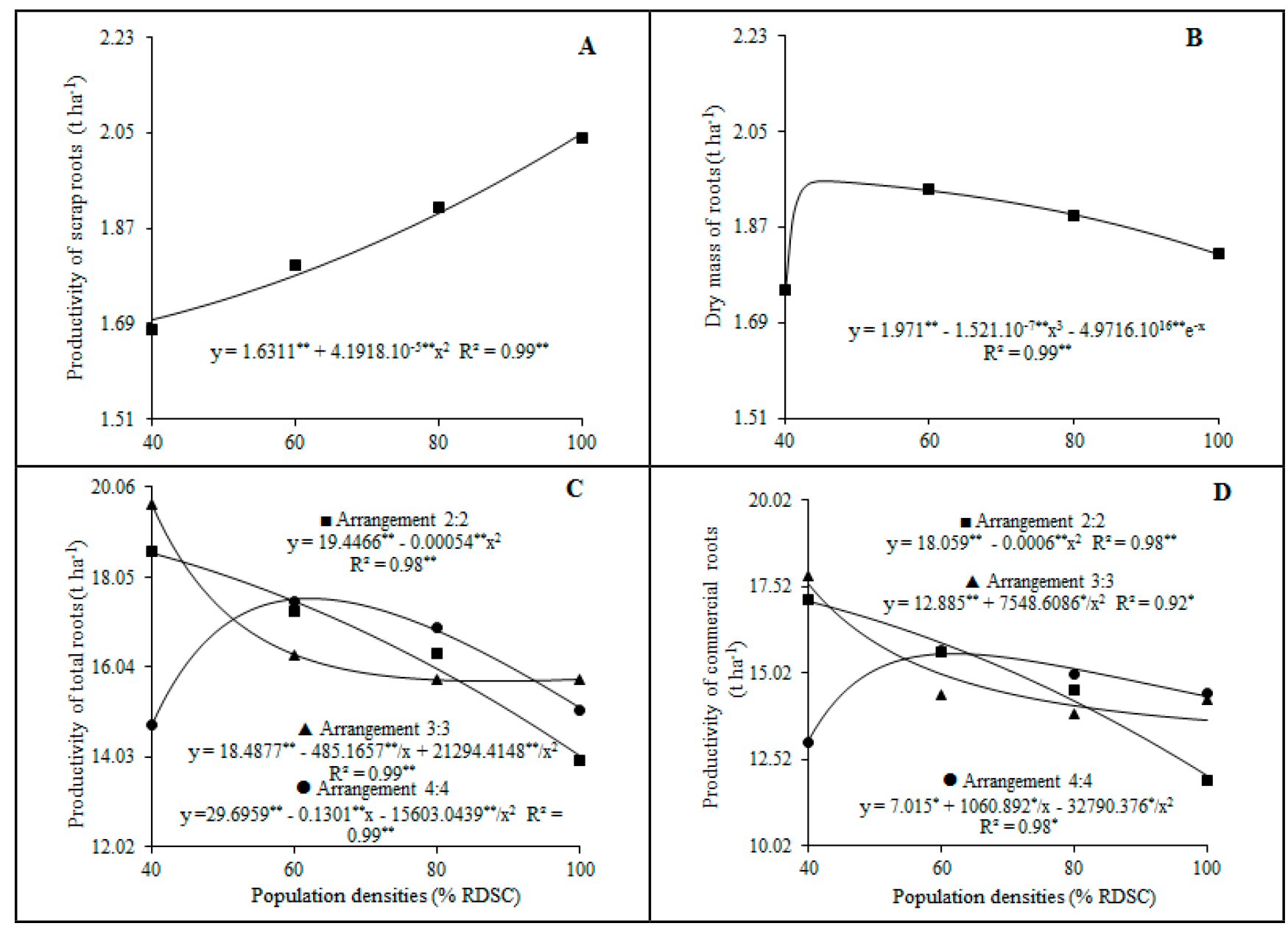

Figure 2. Production of scrap roots (A) and dry mass of beet roots (B) intercropped with cowpea at different densities and production of total (C) and commercially viable roots (D) of beet intercropped with cowpea at different densities and spatial arrangements. Mossoró, UFERSA, 2016-2017.

beet scrap roots, that is, roots with the presence of pests or diseases, irregular colouring, malformed and cracked and that may be consequences of beet plants that were not effective in the use of natural resources due to the increase in the density of vegetable cowpea, to the point of becoming susceptible to these undesirable characteristics. This result agrees in part with that obtained by Ribeiro et al. (2018), who obtained a production of $2.03 \mathrm{t} \mathrm{ha}^{-1}$ scrap roots at a cowpea density of $66 \%$ of RDSC.

Dry mass of roots increased with increasing cowpea densities, reaching maximum value of $1.95 \mathrm{t} \mathrm{ha}^{-1}$ at density of $45.41 \%$ of RDSC, with a subsequent decrease (Figure 2B).

Partitioning the interaction of population densities within each spatial arrangement, the production of total and commercially viable roots decreased with increasing densities in the 2:2 and 3:3 arrangements (Figures $2 \mathrm{C}$ and 2D). On the other hand, within the $4: 4$ arrangement, productivities increased with increasing cowpea densities, reaching maximum values of 17.57 and $15.60 \mathrm{t} \mathrm{ha}^{-1}$ at densities of 62.13 and $61.82 \%$ of RDSC, respectively, with a subsequent decrease (Figures $2 \mathrm{C}$ and 2D). These results are probably due to the lower intraspecific competition between beet plants in this spatial arrangement, associated with increased density of vegetable cowpea. These continuous decreases or after the optimized values can also be related to the adequate density of vegetable cowpea that promotes, or not, an increase in the yield of beet plants up to a maximum point, after which the answer becomes negative, thus producing a decrease in the yield of variables, a behavior explained by the maximum law reported by Almeida et al. (2015).
The results of the analyses of the characteristics evaluated in the cowpea are presented in Table 2. There was a significant interaction between growing season and spatial arrangement for dry mass of green pods and green grains. Interactions were also observed between growing season and cowpea density in terms of the production of green pods, yield and dry mass of green grains and between population density and spatial arrangement for dry mass of green pods.

In terms of length and number of green pods per square meter, no significant differences were observed between growing seasons. However, for the number of green grains per pod and the weight of 100 green grains, statistical differences were recorded between growing seasons, with higher values in the second season. These values may be associated with soil fertility and the material incorporated 


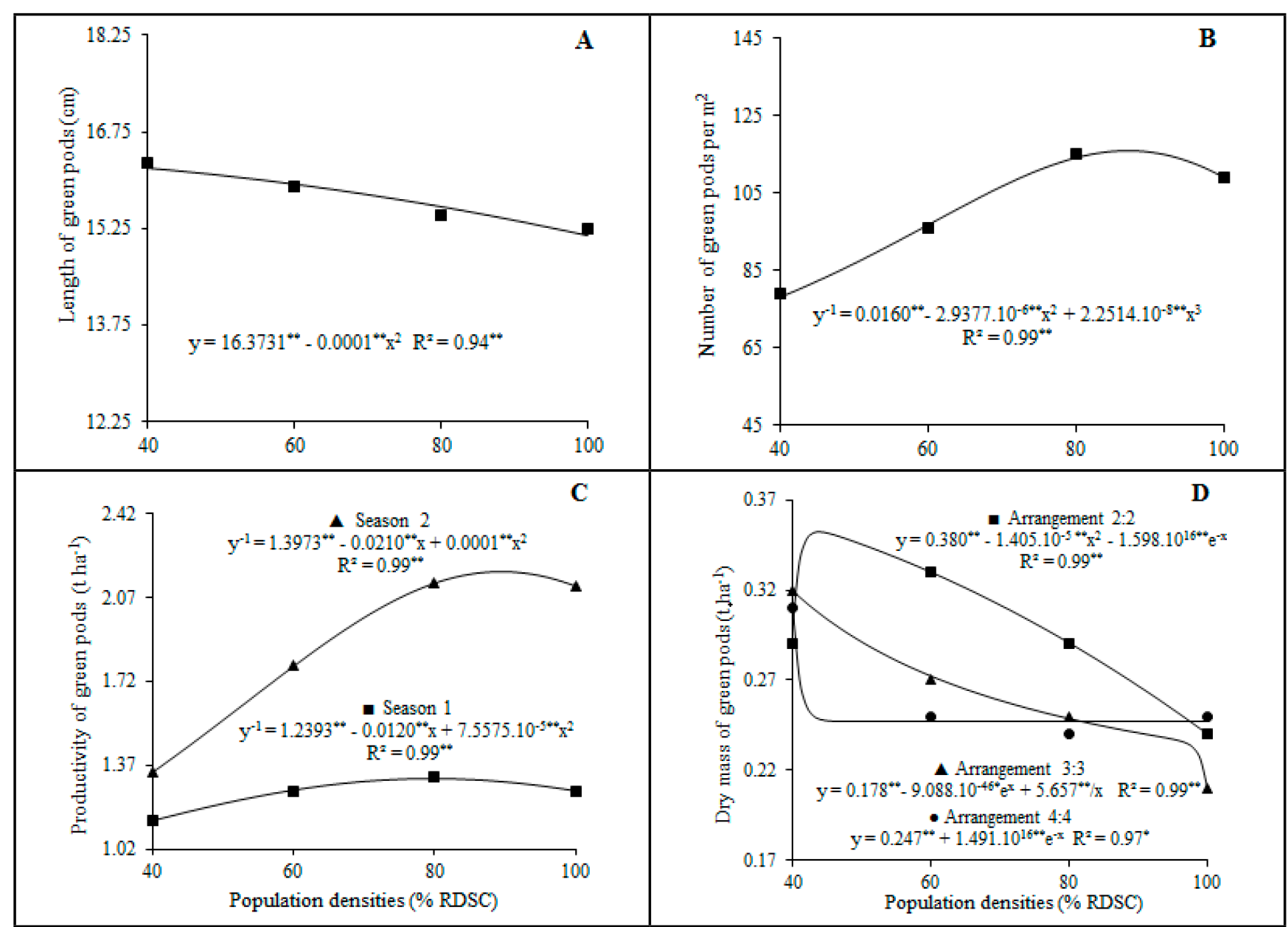

Figure 3. Length of green pods (A) and number of green pods per $\mathrm{m}^{2}(\mathrm{~B})$ of cowpea intercropped with beet at different cowpea densities and production of green pods (C) and dry mass of green pods (D) at different cowpea densities and spatial arrangements. Mossoró, UFERSA, 2016-2017.

in the second growing season, mainly due to the numerical superiority of the chemical element potassium $\left(\mathrm{K}^{+}\right)$. According to Sousa et al. (2013), potassium has numerous functions in the plant, especially the activation of several enzymatic systems, many of them participating in the processes of photosynthesis and respiration. Bezerra Neto et al. (2015) also highlights that plants diagnosed with a lower amount of $\left(\mathrm{K}^{+}\right)$can be harmed in the formation or size of seeds.

There were no significant differences between the spatial arrangements in terms of the length of green pods, the number of pods per square meter, the number of green grains per pod and the weight of 100 green grains. However, for the production of green pods and the yield of green grains, the 2:2 spatial arrangement showed the highest values (Table 2). This behavior for these variables may be associated with less intraspecific competition, mainly due to the lower number of vegetable cowpea plants present in this arrangement.

Partitioning the interaction growing seasons within each population density, the production of green pods and the yield of green grains were higher in the second growing season. In terms of green grain dry matter, higher values were obtained in the second cropping season only at cowpea densities of 40 and $60 \%$ of RDSC. These results show that cowpea plants in the second season were more efficient in using available environmental resources. This is because, the efficient use of natural resources by plants can be related to several factors, among them the chemical composition of the soil and incorporated material, the preparation of the soil, the climatic conditions for that year of cultivation and the cultural treatments carried out during the cultivation.

On the other hand, evaluating the growing seasons within each spatial arrangement, we observed a higher dry mass of green pods in the first season in the 2:2 and 3:3 arrangements compared to the second season and a higher dry mass of green grains in the second season within the 3:3 and 4:4 spatial arrangements compared to the first season. Studying the spatial arrangements within each growing season, we recorded dry mass of green pods and dry mass of green grains were highest in the spatial arrangement 2:2 in the first growing season. In the second season, highest dry mass of pods and dry mass of green grains were observed in the spatial arrangement 4:4. On the other hand, partitioning the spatial arrangements within each population density, higher values of dry mass of 


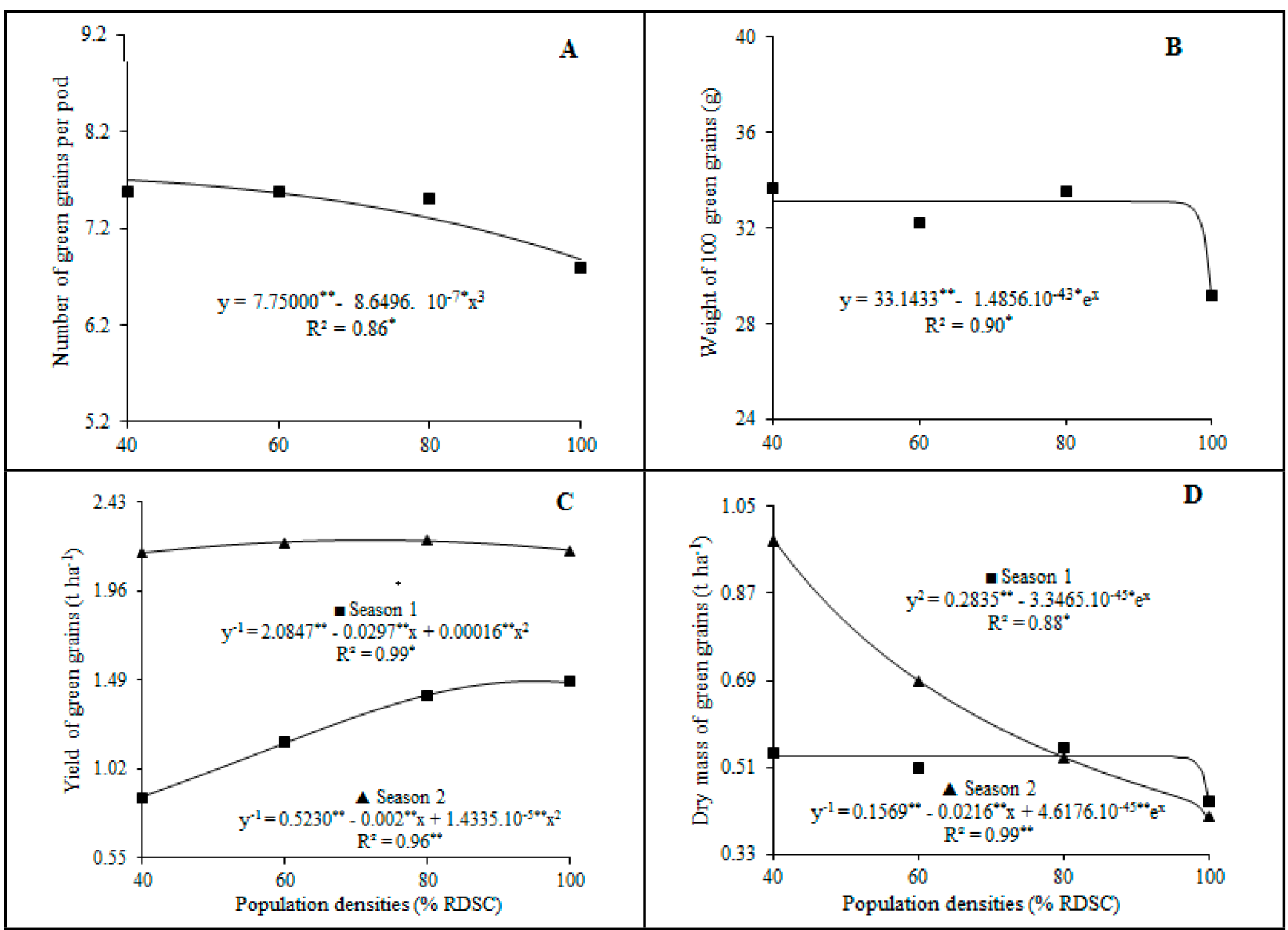

Figure 4. Number of green grains per pod and weight of 100 green grains of cowpea intercropped with beet at different cowpea densities and yield of green grains and dry mass of green grains of cowpea intercropped with beet at two growing seasons and different cowpea densities. Mossoró, UFERSA, 2016-2017.

green pods were observed in the $3: 3$ and $4: 4$ arrangements at a density of $40 \%$ of RDSC and in the 2:2 arrangement at densities of 60 and $80 \%$ of RDSC.

According to Nunes et al. (2018), the behavior related to growth variables may be related to the environmental conditions to which the plants were exposed, resulting in a balance in the translocation of photoassimilates and their conversion, not only in productive variables.

Analysing the behaviour of the characteristics of cowpea as a function of population density, we observed a decrease in the length of green pods (Figure 3A) and in the dry mass of green pods within the $3: 3$ spatial arrangement (Figure 3D). The number of pods per square meter (Figure 3B), the production of green pods within the first and second growing season (Figure 3C), and the dry mass of green pods within the 2:2 spatial arrangement (Figure 3D) increased with increasing cowpea densities, reaching maximum values of 116 pods, 1.31 (season 1) and 2.18 (season 2), and $0.35 \mathrm{t} \mathrm{ha}^{-1}$ (arrangement 2:2) at densities of 86.99, 79.57 (season 1) and 89.35 (season 2), and $44.00 \%$ (arrangement 2:2) of RDSC, with a subsequent decrease. A stable behaviour as a function of cowpea population density was recorded for the dry mass of green pods $\left(0.25 \mathrm{tha}^{-1}\right)$ in the spatial arrangement 4:4 (Figure 3D).

In the number of green grains per pod (Figure 4A) and in the dry mass of green grains in the second growing season (Figure 4D) we also observed a decrease. A stable behaviour as a function of cowpea population density was also recorded for the weight of 100 green grains (33.14 g) (Figure $4 \mathrm{~B})$ and for the dry mass of green grains $\left(0.53 \mathrm{t} \mathrm{ha}^{-1}\right)$ in the first growing season (Figure 4D). The yields of green grains (Figure 4C) within the first and second growing season increased with increasing cowpea densities reaching maximum values of 1.49 (season 1) and $2.23 \mathrm{tha}^{-1}$ (season 2) at densities of 89.35 (season 1) and $79.57 \%$ (season 2) of RDSC, with a subsequent decrease.

The different results presented show that vegetable cowpea is a plant that has reasonable adaptability in different situations of population density. This occurs because, the productive variables reached optimized values promoting an increase in the yield of the plant up to a maximum point, even with an increase in the density of vegetable cowpea plants. According to Shimada et al. (2000), this maximum production value per unit area determines the ideal crop population. This type of situation was also observed in growth analysis variables, since the increase in population density provided 
a reduction on dry mass of green pods and dry mass of green grains, as well as the morphological aspect of the length of green pods, due to greater competition for natural resources.

Ribeiro et al. (2018), studying the number of green pods per square meter, the productivity of green pods, the number of green grains per pod and the yield of green grains as a function of cowpea density in an intercropping system with carrot, observed a parabolic behaviour for these characteristics, i.e. a relationship similar to those obtained in this research with these variables. For the productivity of green pods, the number of green grains per pod and the yield of green grains, the authors observed an increase with increasing cowpea densities, with maximum values of $1.23 \mathrm{t} \mathrm{ha}^{-1}, 5.9$ grains and $0.67 \mathrm{t} \mathrm{ha}^{-1}$ at cowpea densities of $88.6 ; 73.5 \%$ and $87.2 \%$ of the RPSC, respectively.

The results of the analyses of agronomic indexes and of economic efficiency viability evaluated in the cowpea and beet intercropping systems are presented in Table 3 . There was no significant interaction between the production factors, growing seasons, cowpea population densities and spatial arrangements of the component crops in terms of the system productivity index, the land equivalent coefficient and the monetary equivalent ratio.

Significant differences between the indices were recorded between the cropping seasons, except for the SPI, with higher values in the second season. It can be observed that the system productivity index is in accordance with the monetary equivalent ratio, showing that the second season showed a more productive and stable cultivation pattern than that of the first season. The spatial arrangements also differed significantly in the system productivity index, with the highest values in the 2:2 arrangement. This result may be related to less intra and interspecific competition between the crops studied. In other words, we can infer that the average production per plant will be higher in arrangements with a smaller number of plants, but there will not necessarily be a higher production per area. This situation is verified when we observe the productive performance of beet in Table 1. There were no significant differences between the spatial arrangements for LEC and MER.

The system productivity index and the monetary equivalent ratio increased by 2.93 and 0.09 from the lowest to the highest cowpea density, reaching maximum values of $29.23 \mathrm{tha}^{-1}$ and 1.11 at a density of $100 \%$ of RDSC (Figures $5 \mathrm{~A}$ and $5 \mathrm{~B}$ ). The main advantage of SPI is that it standardizes the productivity of the cowpea crop in terms of the main crop (beet). The SPI values obtained in the different growing seasons, in the spatial arrangements and at the highest and lowest cowpea densities were higher than those obtained with the single cultivation of beet (Table 3 and Figures 5A).

On the other hand, for MER, values higher than 1 (unit) were registered in all combinations of the tested production factors, which indicates economic superiority of the intercropping system in relation to the single cropping system of greatest economic expression obtained in the research (Table 3 and Figures 5B).

The land equivalent coefficient increased as a function of increasing cowpea densities up to a maximum value of 0.59 at a cowpea density of $95.58 \%$ of RDSC, with a subsequent decrease (Figure 5B). The obtained values of LEC were higher than 0.25 in all combinations of the production factors, which is the threshold value expressing where interspecific competition is similar to intraspecific competition; and above that value, this index expresses the yield advantage of the intercropped crops relative to their single crops (Table 3 and Figure 5B).

These advantages may result from several mechanisms, but the most common one cited in the literature is that component cultures differ in their use of growth resources in a way that when they are grown in combination, they are able to 'complement' each

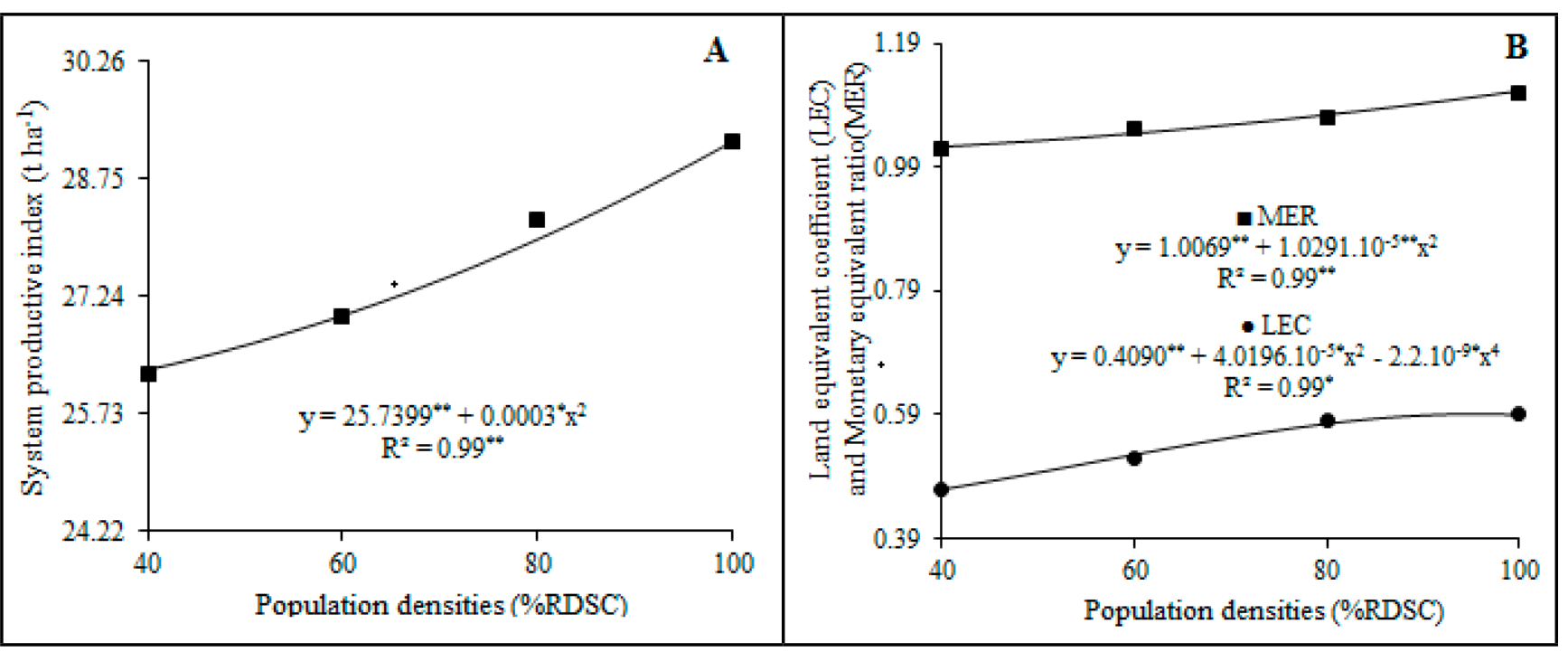

Figure 5. System productive index (A) at different growing seasons, land equivalent coefficient and monetary equivalent ratio (B) of beet cowpea intercropping at different cowpea densities. Mossoró, UFERSA, 2016-2017. 
other, thus making better overall use of resources. In terms of competition, this means that in some way, component cultures do not compete exactly for the same general resources.

In the intercropping systems, it is expected to maximise the degree of complementarity between the component cultures and to minimise competition between, thereby maximising the intercropping advantages determined by the agro-economic indices (Barot et al., 2017).

Ribeiro et al. (2018), evaluating carrot and cowpea intercropping as a function of spatial arrangement and cowpea population density, verified that there was no influence of the planting arrangements on the agro-economic efficiency index tested, the so-called "modified monetary advantage". This result agrees with the agro-economic indices obtained with LEC and MER evaluated in this research. On the other hand, these authors evaluated this same index as a function of increased cowpea density and recorded a higher agroeconomic performance of the carrot $\mathrm{x}$ cowpea intercropping system at a cowpea density of $42 \%$ of the RPSC, with a subsequent decrease. A similar behaviour was recorded only in the LEC index determined in this research, where the highest agronomic performance was reached at a cowpea density of $95.58 \%$ of the RDSC, with a subsequent decrease (Figure 5B).

In view of these complementarity mechanisms, the producer of cowpea and beet in an intercropping system may opt for the best agronomic or economic option that suits the cowpea density to be used in the intercropping system.

Under soil and weather conditions in this study, the maximum production of commercial beet roots was obtained with the productivity of $15.60 \mathrm{t} \mathrm{ha}^{-1}$ at density of $61.82 \%$ of RDSC within the 4:4 arrangement, while the maximum yield of cowpea green grains of $2.23 \mathrm{t}$ $\mathrm{ha}^{-1}$ was reached at density of $79.57 \%$ of RDSC within 2:2 spatial arrangement. The productivities of beet roots of the types extra A, extra AA and great decreased with increasing cowpea population density, without any influence of the tested spatial arrangements. The maximum mean productivity of cowpea green pods of 1.74 was obtained at density of $87.47 \%$ of RDSC, reached within 2:2 spatial arrangement. The maximum economic efficiency of the cowpea-beet intercropping was obtained with MER of 1.11 at cowpea density of $100 \%$ of RDSC, irrespective of the spatial arrangement and growing season.

\section{REFERENCES}

ADETILOYE, PO; ADEKUNLE, AA. 1989. Concept of monetary equivalent ratio and its usefulness in the evaluation of intercropping advantages. Tropical Agriculture 66: 337-341.

ADETILOYE, PO; EZEDINMA, FOC; OKIGBO, BN. 1983. A land equivalent coefficient (LEC) concept for the evaluation of competitive and productive interactions in simple to complex crop mixtures. Ecological Modelling 19: 27-39.

ALMEIDA, AES; BEZERRA NETO, F; COSTA, LR; SILVA, ML; LIMA, JSS; BARROS JÚNIOR, AP. 2015. Eficiência agronômica do consórcio alface-rúcula fertilizado com florde-seda. Revista Caatinga 28: 79-85.

ALVARES, CA; STAPE, JL; SENTELHAS, PC; GONÇALVES, JLM; SPAROVEK, G. 2014. Koppen's climate classification map for Brazil. Metereologische Zeitschrift 22: 711-728.

ANDRADE FILHO, FC. 2012. Bicultivo de folhosas consorciadas com beterraba em função de adubação com flor-de-seda e densidades populacionais. Mossoró: UFERSA. 93p. (M.Sc. dissertation).

ANDRADE JÚNIOR, AS; BARROS, AHC; SILVA, CO; FREIRE FILHO, FR. 2007. Zoneamento de risco climático para a cultura do feijão-caupi no Estado do Ceará. Revista Ciência Agronômica 38: 109-117.

ARAÚJO, AC; BELTRÃO, NEM; BRUNO, GB; MORAES, MS. 2006. Cultivares, épocas de plantio e componentes da produção no consórcio de algodão e amendoim. Revista Brasileira de Engenharia Agrícola e Ambiental 10: 357-363.

BAROT, S; ALLARD, V; CANTAREL, A; ENJALBERT, J; GAUFFRETEAU, F; GOLDRINGER, I; LATA, JC; ROUX, X; NIBOYET, A; PORCHER, E. 2017. Designing mixtures of varieties for multifunctional agriculture with the help of ecology. A review. Agronomy for Sustainable Development 37: 2-20.

BATISTA, TMV; BEZERRA NETO, F; SILVA, IN; SILVA, ML; OLIVEIRA, EQ; BARROS JÚNIOR, AP. 2016. Agronomic efficiency of the intercropping of arugula with carrot under different population combinations. Revista Caatinga 29: 76-84.

BEZERRA NETO, E; BARRETO, LP; COELHO, JBM. 2015. Considerações sobre nutrição mineral e o caso do feijão vigna. Anais da Academia Pernambucana de Ciência Agronômica 11/12: 85-120.
BEZERRA NETO, F; SILVA, ML; VIEIRA, FA; SILVA RCP; SILVA, IN. 2013. Consórcio de beterraba com caupi-hortaliça adubado com diferentes quantidades de flor-de-seda. In: CONGRESSO NACIONAL DE FEIJÃOCAUPI, 3., Recife. Anais... Recife, Instituto Agronômico de Pernambuco. 5p.

EHLERS, E. 1997. Agricultura sustentável Origens e perspectivas de um novo paradigma. São Paulo: Livros da Terra. 178p.

FAVACHO, FS; LIMA, JSS; BEZERRA NETO, F; SILVA, JN; BARROS JÚNIOR, AP. 2017. Productive and economic efficiency of carrot intercropped with cowpea vegetable resulting from green manure and different spatial arrangements. Revista Ciência Agronômica 48: $337-346$

FERREIRA, DF. 2011. Sisvar: A computer statistical analysis system. Ciência e Agrotecnologia 35: 1039-1042.

JANDEL SCIENTIFIC. 1991. Table curve: curve fitting software. Corte Madera: Jandel Scientific. 280p.

MIDMORE, DJ. 1993. Agronomic modification of resource use and intercrop productivity. Field Crops Research 34: 357-380.

MORAES, EC; LIMA, JSS; BEZERRANETO, F; SILVA, JN; NUNES, RLC; LINHARES, PCA. 2018. Habilidade competitiva e biológica do consórcio beterraba com caupi-hortaliça proveniente de adubação verde e de arranjos espaciais. Revista Ceres 65: 433-442.

NUNES, RLC; BEZERRA NETO, F; LIMA, JSS; BARROS JÚNIOR, AP; CHAVES, AP; SILVA, JN. 2018. Agro-economic responsiveness of radish associations with cowpea in the presence of different amounts of Calotropis procera, spatial arrangements and agricultural crops. Ciência e Agrotecnologia 42: 350-363.

OLIVEIRA, LAA; BEZERRA NETO, F; SILVA, ML; OLIVEIRA, OFN; LIMA, JSS; BARROS JÚNIOR, AP. 2015. Viabilidade agronômica de policultivos de rúcula/cenoura/alface sob quantidades de flor-de-seda e densidades populacionais. Revista Caatinga 28: 116-126.

PEREIRA, MFS; BEZERRA NETO, F; PONTES, FST; LINHARES, PCF; SILVA, ML; SILVA, IN. 2016. Productive performance of cowpearadish intercropping under different amounts of rooster tree biomass incorporated into the soil. Revista Brasileira de Engenharia Agricola e Ambiental 20: 965-971.

PINTO, CM; SIZENANDO FILHO, FA; CYSNE, JRB; PITOMBEIRA, JB. 2011. Produtividade e índices competição da mamona consorciada com gergelim, algodão, milho e feijão caupi. Revista Verde de Agroecologia e Desenvolvimento Sustentável 6: 75-85.

RÊGO, LGS; MARTINS, CM; SILVA, EF; SILVA, JJA; LIMA, RNS. 2016. Pedogenesis and soil classification of an experimental farm in Mossoró, state of Rio Grande do Norte, Brazil. Revista Caatinga 29: 1036-1042.

RIBEIRO, GM; BEZERRA NETO, F; LIMA, JSS; SILVA, ML; BARROS JÚNIOR, AP; SANTOS, EC. 2017. Agro-economic efficiency of the intercropping of carrot $x$ cowpea-vegetable under different spatial arrangements and population densities. Revista 
Caatinga 30: 847-854.

RIBEIRO, GM; BEZERRA NETO, F; LIMA, JSS; SILVA, ML; BARROS JÚNIOR, AP; SANTOS, EC. 2018. Productive performance of carrot and cowpea intercropping system under different spatial arrangements and population densities. Revista Caatinga 31: 19-27.

SCHONS, A; STRECK, NA; STORCK, L; BURIOL, GA; ZANON, AJ; PINHEIRO, DG; KRAULICH, B. 2009. Arranjos de plantas de mandioca e milho em cultivo solteiro e consorciado: crescimento, desenvolvimento e produtividade. Revista Bragantia 68: 155-167.

SHIMADA, MM; ARF, O; SÁ, ME. 2000. Comportamento do rendimento e desenvolvimento do feijoeiro de porte ereto sob diferentes densidades populacionais. Bragantia 59: 181-187.

SILVA, IN; BEZERRA NETO, F; BARROS
JÚNIOR, AP; LIMA, JSS; BATISTA, TMV; LINS, HA. 2018. Green manure and spatial arrangement in the sustainability improvement of lettuce-beet intercrops. Revista Brasileira de Engenharia Agricola e Ambiental 22: 451-457.

SILVA, ML; BEZERRA NETO, F; LINHARES, PCF; LIMA, JSS; BARROS JÚNIOR, AP; SÁ, JR; BEZERRA, AKH; PEREIRA, MFS; OLIVEIRA, MKT; FERNANDES, YTD. 2010. Produção classificada de beterraba adubada com jitirana sob diferentes quantidades e tempos de incorporação ao solo. Horticultura Brasileira 28: S1779-S1786.

SILVA, ML; BEZERRA NETO, F; LINHARES, PCF; SÁ, JR; LIMA, JSS; BARROS JÚNIOR, AP. 2011. Produção de beterraba fertilizada com jitirana em diferentes doses e tempos de incorporação ao solo. Revista Brasileira de Engenharia Agrícola e Ambiental 15: 801-809. SILVA, RCP; BEZERRA NETO, F; SILVA, ML;
BARROS JÚNIOR, AP; ALMEIDA, AES; VIEIRA, FA. 2018. Effect of rooster tree green manure on carrot and lettuce intercropping system. Revista Caatinga 31: 551-559.

SOUSA, MDM; CARVALHO, CM; SABINO, RK; LOPES, PH; ALCÂNTARA, VS; SILVESTRE, ACA. 2013. Efeito da adubação potássica no crescimento do feijão de corda preto. Revista Brasileira de Agricultura Irrigada 7: 66-73.

SOUZA, RJ; FONTANETTI, A; FIORINI, CVA; ALMEIDA, K. 2003. Cultura da beterraba: cultivo convencional e cultivo orgânico. Lavras: UFLA. 37p. (Academic text).

STRASSBURGER, AS; PEIL, RMN; SCHWENGBER, JE; MEDEIROS, CAB; MARTINS, DS; SILVA, JB. 2010. Crescimento e produtividade de cultivares de morangueiro de "dia neutro" em diferentes densidades de plantio em sistema de cultivo orgânico. Revista Bragantia 69: 623-630. 